\title{
Retraction Note to: Educational reforms and internationalization of universities: evidence from major regions of the world
}

\author{
Ghulam Akhmat $\cdot$ Khalid Zaman · Tan Shukui • Tauseef Ahmed
}

Published online: 23 April 2014

(C) Akadémiai Kiadó, Budapest, Hungary 2014

\section{Retraction Note to: Scientometrics (2014) 98:2185-2205 DOI 10.1007/s11192-013-1130-5}

The Editor-in-Chief has decided to retract the following article, G. Akhmat et al.: Educational reforms and internationalization of universities: evidence from major regions of the world. Scientometrics 98, pp. 2185-2205, DOI 10.1007/s11192-013-1130-5. Upon investigation carried out according to the Committee on Publication Ethics guidelines, it has been found that the article duplicates paragraphs of various internet sources as well as copied paragraphs from published papers.

In particular the authors duplicated parts from Section $\mathrm{V}$ of a report on The Impact of Education on Economic Growth: Theory, Findings, and Policy Implications by Brian G. Dahlin, Duke University 2008 without proper attribution.

The authors have agreed to the retraction.

The online version of the original article can be found under doi:10.1007/s11192-013-1130-5.

G. Akhmat · T. Shukui $(\bowtie)$

College of Public Administration, Huazhong University of Science and Technology (HUST), 1037 Luoyu Road, Wuhan, People's Republic of China e-mail: tansk@126.com

G. Akhmat

e-mail: ahmad_choudary@hotmail.com

K. Zaman · T. Ahmed

Department of Management Sciences, COMSATS Institute of Information Technology, Abbottabad, Pakistan

e-mail: khalidzaman@ciit.net.pk 